\title{
KONSTRUKSI NALAR RECHTVINDING HAKIM DALAM PEMBERIAN IZIN POLIGAMI YANG BERKEADILAN GENDER DALAM PUTUSAN PENGADILAN AGAMA JOMBANG No. 0899/Pdt.G/2016/PA.Jbg
}

\author{
Abdullah Taufiq, Ilham Tohari
}

IAIN Kediri Jawa Timur. E-mail: abtakediri@gmail.com

\begin{abstract}
The practice of polygamy in Indonesia until now has drawn criticism from some feminists who did not agree. But on the one hand, both Islamic law and positive law permit various conditions. In this case, the Religious Court (PA) becomes the last fence which becomes the determining point for a man to be able to polygamy. For this reason, researchers conducted a study of $P A$ decisions on polygamy, namely Jombang PA Decision No. No. 0899 / Pdt.G / 2018 / PA.Jbg. The focus of the problem is (1) the value of gender justice in the decision and (2) reasoning rechtvinding(legal discovery) judge. The method used in this study is a normative-qualitative legal research method with content analysis techniques from Charles Purse. The results showed that the practice of polygamy licensing in the Religious Courts had actually gone through processes that reflected gender justice. This is reflected in the obligation of the Religious Court to summon the longest wife of the applicant for polygamy to be asked for willingness and information. The results of subsequent studies show that $P A$ Jombang judges used hermeneutic techniques in making legal discovery efforts. Because, they not only focus on aspects of legality, but also consider the contextualization.
\end{abstract}

Keywords: Polygamy, Gender, Rechtvinding.

Abstrak: Praktik poligami di Indonesia hingga saat ini menuai berbagai kecaman dari beberapa kalangan feminis yang tidak menyepakatinya. Namun di satu sisi, hukum Islam maupun hukum positif mengizinkan dengan berbagai syarat. Dalam hal ini, Pengadilan Agama (PA) menjadi pagar terakhir yang menjadi titik penentu seorang laki-laki dapat berpoligami. Untuk itu, peneliti melakukan studi terhadap putusan PA tentang poligami, yakni Putusan PA Jombang No. No. 0899/Pdt.G/2018/PA.Jbg. Fokus permasalahannya adalah (1) nilai keadilan gender di dalam putusan tersebut dan (2) nalar rechtvinding (penemuan hukum) hakim. Metode yang digunakan dalam penelitian ini adalah metode penelitian hukum normatif-kualitatif dengan teknik analisis konten dari Charles Purse. Hasil penelitian menunjukkan bahwa praktik izin poligami di Pengadilan Agama sebenarnya telah melalui proses-proses yang mencerminkan keadilan gender. Hal tersebut dicerminkan dengan kewajiban Pengadilan Agama untuk memanggil istri terlama pemohon poligami untuk dimintai kerelaan dan keterangannya. Hasil penelitian 
selanjutnya menunjukkan bahwa hakim PA Jombang menggunakan teknik hermeneutika dalam melakukan upaya penemuan hukum. Sebab, mereka tidak hanya fokus terhadap aspek legalitasnya, tetapi juga mempertimbangkan kontekstualisasinya.

Kata Kunci: Poligami, Gender, Rechtvinding.

\section{Pendahuluan}

Dialektika tentang wanita dan kedudukannya dalam realitas drama kehidupan sosial selalu menjadi wacana yang aktual untuk diteliti. Dalam struktur sosial yang berkembang di masyarakat, perempuan kebanyakan diposisikan sebagai kaum inferior. Hal tersebut menjadi efek dari bangsa yang secara umum bermazhab patriarki (memuliakan kaum lelaki dalam semua aspek kehidupan). ${ }^{1}$

Untuk itu, diperlukan penelitian maupun kajian mendalam terhadap masalah ketimpangan derajat antara laki-laki dan perempuan. Perempuan sebagai makhluk yang inferior secara rasio dan nilai dapat dibenarkan jika mengacu pada potret kehidupan sosial di zaman dahulu. Namun, kesadaran manusia di era kontemporer ini semakin berkembang sehingga wajar jika ada upaya untuk membenahi institusi sosial yang bias gender.

Para ahli tafsir konvensional dengan gigih dan keyakinan kuat masih mempertahankan postulat bahwa kaum laki-laki boleh menikahi lebih dari satu wanita. Dengan hasil penafsiran yang paternalistik dan syarat akan kepentingan laki-laki ini, kaum feminis melihat bahwa kaum wanita dalam kehidupan sosial keagamaan masih belum terbebas dari keterkungkungan dominasi laki-laki.

Menurut kaum feminis, dari hasil penafsiran ayat tersebutlebih ironis lagi-dijadikan sumber hukum dalam membuat Undang-undang (UU) No. 1 Tahun 1974 tentang Perkawinan. Lebih spesifik lagi terdapat dalam Pasal 3 Ayat (1) dan (2) UU No. 1 Tahun 1974:

1) Pada asasnya dalam suatu perkawinan seorang pria hanya boleh mempunyai seorang istri. Seorang wanita hanya boleh mempunyai seorang suami.

${ }^{1}$ Nasaruddin Umar, Argumentasi Kesetaraan Gender Perspektif al-Qur'an (Paramadina: Jakarta, 1999), 73. 
2) Pengadilan, dapat memberi izin kepada seorang suami untuk beristri lebih dari seorang apabila dikehendaki oleh pihakpihak yang bersangkutan. ${ }^{2}$

Mereka menilai pasal tersebut bernuansa paradoks dan ambigu. Sebab, di ayat pertama menjelaskan bahwa asasnya perkawinan di Indonesia adalah monogami, tetapi mengapa di ayat selanjutnya berbicara yang sebaliknya? Ini adalah bentuk inkonsistensi dan ketidakpastian hukum. Kalau UU Perkawinan memang berniat untuk menegakkan asas poligami, pasal kedua selayaknya ditiadakan. Oleh karenanya, yang bias tidak hanya gender, tetapi merambah UU Perkawinan juga.

Hakim dihadapkan pada posisi dilematis di antara dua kutub yang berseberangan. Satu sisi ia harus mengedepankan nilai luhur moral yang diyakini masyarakat, tetapi di sisi lain ia tak dapat mengabaikan keterikatannya dengan undang-undang. Diskursus antara kepastian hukum dan keadilan benar-benar dikontestasikan dalam perkara pengajuan izin poligami. Upaya untuk memperjuangkan keadilan dan kesetaraan memang harus tetap diutamakan, tetapi aspek kepastian hukum dalam undang-undang juga tak dapat luput dari pertimbangan. Oleh karena itu, diperlukan mekanisme ijtihad yang mampu menjembatani celah yang terbentuk antara keduanya. Dalam hal ini, rechtvinding adalah wasilah yang representatif.

Penelitian ini dimaksudkan untuk mengeksplorasi ijtihad hakim dalam memutus perkara yang dihadapkan kepadanya. Bagaimana pula nalar rechtvinding diterapkan dalam memutus suatu perkara mengingat aturan poligami diatur secara sah dalam UU Perkawinan, namun sekaligus ditentang oleh sekelompok masyarakat. Persoalan tentang ijtihad hakim dalam putusan izin poligami yang mencerminkan dan menjiwai nilai keadilan gender itulah yang menjadi inti kajian yang akan dianalisis.

Penelitian ini mengambil Putusan Pengadilan Agama Kabupaten Jombang No. 0899/Pdt.G/2016/PA.Jbg tentang pengajuan poligami yang sudah dikabulkan sebagai objek material penelitian. Selain itu, penulis akan menjabarkan pandangan

${ }^{2}$ Kitab Undang-undang Hukum Perdatadan Peraturan Perundang-undangan Lainnya,(Surabaya: Graamedia Press, 2013), 423-424. 
masyarakat tentang keadilan gender dalam poligami sebagai data penunjang demi menambah validitas penelitian.

\section{Kontruksi Nalar Rechtsvinding Hakim}

Konstruksi nalar adalah bangunan atau alur argumen, dalil, dan dasar hukum yang dijadikan landasan oleh hakim pengadilan agama dalam memutus suatu perkara yang dihadapkan kepadanya. Konstruksi nalar juga mencakup sistematika pertimbangan yang masuk akal dengan didasarkan pada peraturan perundang-undangan dan rasa keadilan yang berkembang di masyarakat.

Rechtvinding Hakim adalah upaya penemuan hukum yang dilakukan oleh hakim. Penemuan hukum yang dimaksud dapat berupa penafsiran ataupun konstruksi hukum. Penafsiran digunakan ketika aturan hukumnya ada namun kurang aplikatif sehingga perlu penjelasan lebih luas lagi. Sedangkan konstruksi hukum dipakai manakala aturan hukum yang mengatur suatu perkara tidak ada sama sekali, sedangkan unsur kepastian hukum menjadi isu utama. Maka dari itu, hakim harus mengambil langkah taktis dengan mengonstruksikan hukum itu sendiri lewat beberapa cara.

Rechtvinding atau lebih dikenal dengan istilah penemuan hukum atau hermeneutika hukum adalah proses pembentukan hukum oleh hakim atau aparat hukum lainnya yang ditugaskan untuk menerapkan peristiwa hukum pada peristiwa hukum konkret. Penemuan hukum dilakukan oleh karena undang-undang tidak lengkap atau tidak jelas, hakim harus mencari hukumnya dan harus menemukan hukumnya (rechtsvinding).

Hakim tidak boleh semena-mena mengabaikan nilai yang berkembang di masyarakat demi menghasilkan suatu putusan. Sebab di dalam Pasal 5 Ayat (1) Undang-Undang No. 48 Tahun 2009 tentang Kekuasaan Kehakiman telah mengamanatkan bahwa hakim dan hakim konstitusi wajib menggali, mengikuti, dan memahami nilai-nilai hukum dan rasa keadilan yang hidup dalam masyarakat.

Metode-metode dalam penemuan hukum secara prinsip terbagi menjadi dua, yakni metode interpretasi (intepretation method) dan metode konstruksi hukum atau penalaran (redeneerveijzen). Interpretasi hukum terjadi apabila terdapat ketentuan undangundang yang secara langsung dapat ditetapkan pada peristiwa konkret yang dihadapi, metode dilakukan dalam hal peraturannya 
sudah ada, tetapi tidak jelas untuk dapat diterapkan pada peristiwa konkret karena terdapat norma yang kabur (vage normen), konflik antar norma hukum (antinomy normen), dan ketidakpastian suatu peraturan perundang-undangan. ${ }^{3}$

Konstruksi hukum digunakan jika tidak didapati ketentuan undang-undang yang secara langsung dapat diterapkan pada isu hukum yang dihadapi, atau dalam hal peraturannya tidak ada. Dalam metode konstruksi hukum, ada empat metode yang digunakan oleh hakim pada saat penemuan hukum, yaitu: argumentum per-analogium (analogi), argumentum a contrario, penyempitan hukum, dan fiksi hukum. ${ }^{4}$ Berikut ini dijelaskan lebih lanjut:

1. Metode Interpretasi

Interpretasi atau penafsiran hukum merupakan salah satu metode penemuan hukum. ${ }^{5}$ Metode interpretasi hukum meliputi interpretasi gramatikal, interpretasi historis undang-undang, interpretasi sistematis, interpretasi teleologis, dll.

Pertama, interpretasi gramatikal adalah menafsirkan katakata atau istilah dalam perundang-undangan sesuai dengan kaidah bahasa hukum yang berlaku, yakni memberikan makna terhadap suatu aturan hukum melalui penalaran hukum untuk diterapkan terhadap teks yang kabur atau kurang jelas. ${ }^{6}$

Kedua, interpretasi sistematis adalah metode menafsirkan peraturan perundang-undangan dengan menghubungkannya dengan peraturan hukum yang lain atau dengan keseluruhan sistem hukum. Interpretasi sistematis ini menerapkan prinsip, bahwa peraturan perundang-undangan satu negara merupakan sebuah sistem yang utuh. ${ }^{7}$

Ketiga, interpretasi historis adalah metode penafsiran terhadap makna undang-undang menurut terjadinya dengan cara meneliti sejarah, baik sejarah hukumnya maupun sejarah terjadinya undang-undang

${ }^{3}$ Bambang Sutiyoso, Metode Penemuan Hukum (Yogyakarta: UII Press, 2006), 60.

${ }^{4}$ Ahmad Rifai, Penemuan Hukum..., 60.

${ }^{5}$ Sudikno Mertokusumo, Bab-bab tentang..., 13.

6 Johny Ibrahim, Teori dan Metodologi Penelitian Hukum Normatif, (Malang: Bayumedia, 2011), 221.

7 Ahmad Rifai, Penemuan Hukum..., 67. 
Keempat, interpretasi teleologis adalah penafsiran terhadap undang-undang sesuai dengan tujuan pembentukannya.

Kelima, interpretasi komparatif adalah metode penafsiran dengan jalan membandingkan antara berbagai sistem hukum. Metode ini digunakan oleh hakim pada saat menangani kasuskasus yang menggunakan dasar hukum positif yang timbul dari perjanjian internasional. ${ }^{8}$

2. Metode Konstruksi Hukum

Pertama, metode Argumentum per Analogium (analogi) merupakan metode penemuan hukum dengan cara hakim mencari esensi yang lebih umum dari sebuah peristiwa hukum atau perbuatan hukum baik yang telah diatur oleh undangundang maupun yang belum ada peraturannya.

Kedua, metode Argumentum a Contrario merupakan metode penemuan hukum yang memberikan kesempatan kepada hakim untuk melakukan penemuan hukum dengan pertimbangan bahwa apabila undang-undang menetapkan hal-hal tertentu untuk peristiwa tertentu, berarti peraturan itu terbatas pada peristiwa tertentu itu dan bagi peristiwa di luarnya berlaku kebalikannya. ${ }^{9}$

Ketiga, metode penyempitan hukum/konkretisasi hukum (rechtsvervijning). Sebuah contoh pasal 1365 tentang perbuatan melawan hukum (onrechtmatig daad) yang ruang lingkupnya terlalu luas, maka hakim terlebih dahulu harus mempersempit ruang lingkupnya atau harus dikonkrtkan dan dihubungkan dengan peristiwa konkret yang terjadi.

Keempat, metode fiksi hukum. fiksi hukum diartikan sebagai sebuah asas bahwa setiap orang (yang dianggap cakap hukum oleh undang-undang) dianggap mengerti dan paham akan hukum (undang-undang). Fungsi lain dari fiksi hukum adalah menciptakan stabilitas hukum, juga mengisi kekosongan undangundang. ${ }^{10}$

8 Ibid., 69.

${ }^{9}$ Ahmad Rifai, Penemuan Hukum..., 81.

${ }_{10}$ Ahmad Ali, Menguak Tabir Hukum: Suatu Kajian Filosofis dan Sosiologis (Jakarta:

Gunung Agung, 2002), 88. 


\section{Nilai Keadilan Gender dalam Poligami}

\section{Definisi}

Secara etimologis, poligami atau polygamia adalah kata yang berasal dari bahasa Yunani yakni polus dan gomes. Polus artinya banyak sedangkan gomes berarti kawin. Maka dari itu, poligami sendiri masih dipisahkan menjadi dua istilah yang lebih khās (spesifik) yaitu poligini dan poliandri. Poligini bermakna seorang suami yang mengawini beberapa istri, sedangkan poliandri adalah kebalikannya, yakni istri yang mengawini beberapa suami. Poligami yang diwacanakan sebenarnya adalah poligini saja dan tidak termasuk poliandri. Sebab di dalam Islam sendiri, poliandri dilarang sedangkan poligini diperbolehkan dengan syarat dan batasan tertentu. ${ }^{11}$

2. Poligami di Mata Ulama Feminis

Ada berbagai teori tentang wacana poligami dan keabsahannya di era kontemporer saat ini yang masuk pada item diskursu Poligami

a. Siti Musdah Mulia

Siti Musdah Mulia adalah seorang feminis asal Indonesia yang menyerukan penghapusan poligami secara totalitas dan menerapkan asas monogami. Ia melancarkan kritik terhadap aturan poligami di Indonesia.

Inti dari hasil pemikirannya adalah bahwa Islam sama sekali tidak menganjurkan poligami. Islam adalah agama yang menjunjung keadilan tetapi poligami lebih mengarah pada aspek madarah daripada mașlahah. ${ }^{12}$

b. Asghar Ali Engineer

Kedua adalah Ashgar Ali Engineer. Seorang aktivis gender asal India yang gencar memperjuangkan hak-hak wanita. Ia meninggal pada tahun 2013. Karya-karyanya terbilang cukup banyak dan mencakup beberapa bidang

${ }^{11}$ Gavin W. Jones, Marriage and Divorce in Islamic South East Asia (Oxford: Oxford University Press, 1994), 268.

12 Siti Musdah Mulia, Islam Menggugat Poligami (Jakarta: PT. Gramedia Pustaka Utama, 2004), hlm. 135-141 
keilmuan. Salah satunya adalah The Qur'an Women and Modern Society. ${ }^{13}$

c. Amina Wadud

Ketiga, Amina Wadud melihat bahwa poligami yang ada di dalam al-Quran Surat al-Nisā': 3 adalah tentang perlakuan seorang wali (guardian) terhadap anak yatim. Memahami alNisā': 3 tidak boleh terlepas dengan ayat sebelumnya, yakni di ayat duanya. Pada ayat dua disebutkan bahwa beberapa wali tidak bisa mengelola harta anak yatim dengan adil, maka di ayat tiganya terdapat salah satu solusi untuk menikahinya karena nantinya si suami akan bertanggung jawab untuk memenuhi kebutuhan ekonomi si istri (anak yatim) tadi. Berbeda dengan statusnya yang sebelumnya adalah walinya. Seorang wali hanya berkewajiban mengelola harta anak yatim, bukan menafkahi dari harta pribadi walinya ia memberikan statemen poligami sebagai pemenuhan nafsu belaka.

Terbaca secara jelas di dalam al-Qur'an bahwa poligami sebenarnya bukanlah solusi yang membahagiakan maka dari itu, al-Qur'an memformulasikan poligami dalam ruang lingkup yang terbatas. Sangat jelas bahwa al-Qur'an "enggan" untuk mengizinkan poligami kecuali dengan kondisi tertentu. $^{14}$

\section{Nilai Keadilan Gender dalam Poligami}

Gender adalah suatu konsep kultural yang berupaya menciptakan perbedaan (distinction) dalam hal peran, perilaki, mentalitas dan karakteristik emosional antara laki-laki dan perempuan yang berkembang dalam masyarakat. ${ }^{15}$

Ada empat kategori penilaian keadilan gender. Pertama, adanya kesempatan yang sama bagi perempuan dan laki-laki pada sumber daya pembangunan. Kedua, berpartisipasi secara bersama dalam

13 Asghar Ali Engineer, The Qur'an Women and Modern Society: Second Edition. (New Delhi: New Dawn Press, 2005), 87.

14 Amina Wadud. Inside the Gender Jihad: Women's Reform in Islam. (London: Oneworld, 2006), 23.

${ }^{15}$ Nasaruddin Umar, Argumentasi Kesetaraan Gender..., 33-34. 
mengambil keputusan. Ketiga, adanya kekuasaan yang sama. Keempat, adanya manfaat yang sama. ${ }^{16}$

Yang dimaksud nilai keadilan gender dalam poligami adalah keadilan dan kesetaraan antara kaum laki-laki dengan perempuan. Dengan kata lain, bagaimana kesamarataan hubungan dapat terjalin secara seimbang antara keduanya. Dalam konteks poligami-yang mana suami menikahi lebih dari satu istri-upaya untuk memunculkan perilaku yang berkeadilangender dituntut untuk diaplikasikan dalam setiap lini kehidupan berumah tangga.

\section{Gambaran Umum Pengadilan Agama Jombang}

1. Sejarah Pengadilan Agama Jombang

Kota Jombang termasuk bagian wilayah Kerajaan Majapahit yang menjadi pusat Kerajaan Hindu di Jawa, namun tidak terlepas dari pengaruh Islam yang mulai tersebar pada saat itu. Oleh karena itu sistem peradilan dalam masyarakat Jombang juga dipengaruhi oleh sistem hukum Islam. Hal ini dapat dilihat apabila terdapat perkara-perkara seperti perkawinan, perceraian, dan warisan cukup diajukan kepada penghulu yang menerima dan memutus perkara. ${ }^{17}$

Sejak pemerintahan Hindia Belanda mengeluarkan stbld. No. 152 tahun 1882, keberadaan pengadilan agama secara formal diakui dalam pemerintahan tetapi tidak pernah diperhatikan keberadaannya, kemudian disusul dengan keluarnya stbld. Tahun 1973 No. 116 dan 610 sebagai penyempurnaan Stbld. tahun 1882 No. 152, akan tetapi kenyataannya mengurangi kewenangan yang semula dijalankan oleh pengadilan agama yaitu masalah waris dicabut menjadi kewenangan pengadilan negeri dengan memakai dasar hukum yang berlaku.

Pengadilan Agama Jombang dibentuk sekitar tahun 1908 berdasarkan Stbld. 152 Tahun 1882, yang langsung diketuai oleh K. Mas Ngabai Sosro Oelomo dan berlokasi di halaman masjid agung Jombang. Pada Tahun 1942 Indonesia diduduki oleh

${ }^{16}$ Herien Puspitawati, "Pengenalan Konsep Gender, Kesetaraan, dan Keadilan Gender" dalam Makalah yang disampaikan pada Rapat Koordinasi Kesetaraan Gender se-Wilayah 1 Bogor. (Kamis, 22 Maret 2012), 16.

17 "Sejarah Pengadilan Agama Jombang" dalam http://www.pajombang.go.id/sejarah-pa, diakses pada 1 Januari 2019. 
Jepang dan peradilan agama tetap dipertahankan serta tidak mengalami perubahan kecuali namanya diganti dengan "Soorioo Hooin" untuk peradilan agama dan "Kaikooo Kotoo Hooin" untuk mahkamah Islam tinggi berdasarkan aturan peralihan pasal 3 Onasu Seizu, tanggal 7 Maret 1942 No. $1 .^{18}$

2. Wilayah Yurisdiksi Pengadilan Agama Jombang

Pengadilan Agama Jombang adalah salah satu instansi pemerintah di bawah naungan Mahkamah Agung yang menangani masalah hukum perdata pada bidang perkawinan, kewarisan, wasiat, hibah, wakaf, sedekah, dan ekonomi syariah di antara orang Islam di kota Jombang. Pengadilan Agama Jombang meliputi wilayah hukum yang terdiri dari 21 kecamatan, 301 desa, dan 5 kelurahan.

Pengadilan Agama Jombang berkedudukan di kota Jombang sebagai pengadilan di tingkat pertama kelas I B dengan alamat di jl. Yos Sudarso Desa Denanyar Kecamatan Kabupaten Jombang. Telp./Fax.: 0321851337 / 0321 861337, website http://www.pa-jombang.go.id/.

Luas wilayah kabupaten Jombang adalah $115.950 \mathrm{Ha}$ : $1.159,5 \mathrm{Km}^{2} .^{19}$ Kondisi obyektif kabupaten jombang yang juga menjadi wilayah hukum atau yurisdiksi Pengadilan Agama Jombang adalah sebagai berikut:

Letak geografis Kabupaten Jombang $7.20^{\circ}-7.45^{\circ}$ : Lintang Selatan, dan $5.20^{\circ}-5.30^{\circ}$ : Bujur Timur. Sedangkan luas dan batas-batas wilayahnya yaitu sebelah utara berbatasan dengan Kabupaten Lamongan, sebelah selatan berbatasan dengan Kabupaten Kediri, sebelah timur berbatasan dengan Kabupaten Mojokerto, dan sebelah barat berbatasan dengan Kabupaten Nganjuk.

\section{Deskripsi Putusan No. 0899/Pdt.G/2016/Pa.Jbg}

Surat Permohonan yang memuat keterangan sebagai berikut:

1. Pemohon telah menikah dengan Termohon pada hari Senin, 16 Februari 2004 bertepatan dengan tanggal 25 Zulhijah 1424 H di hadapan pejabat Kantor Urusan Agama.

18 Ibid.

19 "Detail Kabupaten Jombang” dalam depdagri.co.id, diakses tanggal 2 Juni 2019. 
2. Saat terjadi perkawinan tersebut, Pemohon dan Termohon berstatus perjaka dan perawan

3. Awalnya, Pemohon tinggal di Jombang, tetapi akhirnya ia pindah tugas ke Surabaya selama beberapa bulan kemudian berpindah lagi Malang hingga saat ini. Atas tanggung jawab pekerjaan, Pemohon memilih tinggal di Malang. Namun, setiap akhir pekan Pemohon akan menyempatkan waktu untuk pulang ke Jombang.

4. Antara Pemohon dan Termohon sama-sama terjalin hubungan yang harmonis dan rukun. Mereka juga dikaruniai dua anak kandung, dan pada saat ini Termohon juga sedang mengandung 6 bulan dari hasil perkawinannya dengan Pemohon. Kedua anakanak mereka semuanya perempuan. Yang tertua berusia 11 tahun 7 bulan dan yang kedua berusia 5 tahun 8 bulan.

5. Selama perkawinan berjalan, Pemohon dan Termohon mempunyai harta bersama berupa:

a. Sebidang tanah perumahan dengan luas $65 \mathrm{~m}^{2}$ di Desa Watugede, Kecamatan Singosari, Kabupaten Malang dengan batas-batas sebagai berikut:

1) Sebelah Utara: Jalan Perumahan

2) Sebelah Timur : Rumah milik Tyas

3) Sebelah Selatan : Rumah milik Purwanto

4) Sebelah Barat: Rumah milik Yoke Paulina

b. Sebidang tanah pekarangan sebagaimana tercatat dalam Pethok D No. 34 Persil No. 5 Kelas I seluas $268 \mathrm{~m}^{2}$ yang terletak di Desa Ngampungan, Kecamatan Bareng, Kabupaten Jombang dengan batas-batas sebagai berikut:

1) Sebelah Utara: Tanah Pekarangan Sdr. Suki dan Sulkan

2) Sebelah Timur : Jalan Dusun Wungurejo;

3) Sebelah Selatan :Tanah Pekarangan Sdr. Suwarto;

4) Sebelah Barat: Tanah Pekarangan Sdr. Saudi

c. Satu motor matic merek Yamaha dengan nomor registrasi $\mathrm{S}$ 5836 YM tahun 2011 tercatat atas nama Pemohon

d. Satu motor gede merek Yamaha dengan nomor registrasi $\mathrm{S}$ 2034 ZQ tahun 2013 tercatat atas nama Pemohon

Alasan Pemohon ingin menikah lagi dikarenakan Termohon tidak bersedia diajak untuk pindah dan menetap di Kabupaten Malang dengan alasan merawat orang tuanya. Oleh karenanya, 
Pemohon beranggapan kalau Termohon tidak dapat menjalankan kewajibannya sebagai istri. Selain itu, Pemohon sangat khawatir akan melakukan perbuatan yang diharamkan oleh norma agama apabila Pemohon tidak diizinkan untuk berpoligami. Di samping, pemohon sering berada di Malang karena tuntutan pekerjaan.pendapat senada juga disampaikan oleh Husni Tamrin Hakim Pengadilan Agama Kab. Kediri." ${ }^{20}$ Bahwa yang menjadi pertimabangan hakim dalam memberikan izin poligami selain ketentuan Pasal 41 PP.9 Tahun 1975 dan Pasal 55 KHI (tentang beristeri lebih satu orang ) adalah pertimbangan maslahah dan Madharat"

Dalam Surat Permohonannya, Pemohon mengaku siap untuk memenuhi kebutuhan hidup istri-istri beserta anak-anaknya sebab ia adalah karyawan Kompas Gramedia dengan gaji setiap bulannya sebesar Rp. 5.800.000 dan mempunyai usaha bengkel las pembuatan pagar, kanopi, serta teralis dengan pendapatan bersih setiap bulannya sekitar Rp 6.000.000.

Setelah dibacakan Surat Permohonan tersebut, Termohon telah memberikan jawaban secara lisan yang pada pokoknya Termohon bersedia kalau Pemohon menikah lagi dengan wanita lain asalkan Pemohon dapat berbuat adil terhadap Termohon dan istri keduanya

\section{Pertimbangan Hukum}

Dalam putusannya, hakim menilai semua bukti berupa suratsurat maupun saksi-saksi yang diajukan Pemohon telah memenuhi syarat sehingga memiliki daya pembuktian yang kuat.

Di samping itu, hakim dalam hal ini menyamakan antara pengakuan dengan kesediaan Termohon untuk dipoligami. Jadi, pada dasarnya, pengakuan itu adalah alat bukti terkuat dan sempurna di dalam sistem peradilan perdata, hal ini didasarkan pada pasal 174 HIR.

Kemudian, dasar hukum yang digunakan hakim adalah Pasal 4 Ayat (2) Undang-Undang Nomor 1 Tahun 1974 tentang Perkawinan yang isinya menerangkan bahwa Pengadilan hanya memberikan izin kepada seorang suami yang akan beristri lebih dari seorang apabila:

1) Istri tidak dapat menjalankan kewajibannya sebagai istri;

${ }^{20}$ Wawancara dengan Husni Tamrin ( Hakim PA Kab Kediri),Rabo,21 Agustus 2019 . 
2) Istri mendapat cacat badan atau penyakit yang tidak dapat disembuhkan;

3) Istri tidak dapat melahirkan keturunan.

Hakim memaknai syarat-syarat yang diatur di dalam pasal tersebut di atas sebagai syarat alternatif. Artinya, jika salah satu di antaranya telah terpenuhi, maka alasan tersebut dapat dijadikan pertimbangan dalam mengajukan permohonan izin poligami ke Pengadilan Agama.

Dalam hal ini, hakim berpendapat bahwa keadaan Termohon yang tidak bersedia diajak oleh Pemohon untuk tinggal di Kabupaten Malang karena harus merawat orang tuanya di Kabupaten Jombang tidak memenuhi sama sekali syarat kumulatif yang telah di atur di dalam undang-undang

Namun, di samping syarat alternatif tersebut, hakim berpendapat kalau pemohon sudah memenuhi syarat kumulatif yang telah diatur di dalam Pasal 5 Ayat (1) Undang-Undang Nomor 1 Tahun 1974 tentang Perkawinan bahwa untuk dapat mengajukan permohonan izin poligami ke Pengadilan Agama, Pemohon/suami juga wajib memenuhi syarat kumulatif sebagai berikut:

1) Adanya persetujuan dari istri/istri-istri;

2) Adanya kepastian bahwa suami mampu menjamin keperluan hidup istri-istri dan anak-anaknya;

3) Adanya jaminan bahwa suami akan berlaku adil terhadap istri-istri dan anak-anaknya.

Pendapat demikian juga dikuatkan oleh Munadhirah, Hakim Pengadilan Agama Lamongan, ${ }^{21}$ Bahwa pemberian izin poligami juga didasarkan pada pertimbangan yuridis yaitu Pasal 35 s/d 37 Undang undang Perkawinan (Tentang harta bersama) Pasal $40 \mathrm{~s} / \mathrm{d}$ 44 PP no 9 Tahun 1975 ( Tentang beristeri lebih dar seorang )"

\section{Amar Putusan} bahwa:

Dari hasil pertimbangan hukum tersebut, hakim mengadili

1) Mengabulkan permohonan Pemohon;

${ }^{21}$ Siti Munadhirah, Hakim PA Kab Lamongan, Wawancara, Jum `at 30 Agustus 2019. 
2) Memberikan izin kepada Pemohon untuk menikah (lagi) dengan seorang perempuan yang tinggal di Kabupaten Malang sebagai istri kedua;

3) Menetapkan tanah, maupun kendaraan yang sudah disebutkan di dalam Surat Permohonan sebagai harta bersama

4) Membebankan kepada Pemohon untuk membayar biaya perkara sebesar Rp 2.686.000.

\section{Tipologi Hakim Pengadilan Agama Jombang}

Berdasarkan tipologi hakim yang telah peneliti uraikan di dalam Bab II, maka para hakim Pengadilan Agama Jombang terklasifikasikan ke dalam tipe hakim yang Nonposivistik, Kontekstual dan Pragmatis. Sifat-sifat tersebut tercermin di dalam pertimbangan hukum ketika memutus perkara izin poligami yang dihadapkan pada mereka. Ketiga sifat tersebut menurut peneliti adalah bentuk konsistensi alur pikir para hakim yang berorientasi pada outcome (hasil). Sebab, menjadi seorang non-positivistik saja tidak cukup. Diperlukan pula gaya berpikir yang kontekstual dan pragmatis. Seorang hakim boleh jadi tidak terikat dengan undangundang, tetapi gagasannya terlalu idealis sehingga tidak memiliki daya praksis atau tidak dapat diimplementasikan.

\section{Nalar Rechtvinding Hakim Pengadilan Agama Jombang}

1. Tahapan Penemuan Hukum

Pertama, hakim akan mencoba mengkonstatir atau menentukan ada atau tidaknya suatu perkara yang diajukan kepadanya. Dalam konteks penelitian ini, hakim Pengadilan Agama Jombang perlu memastikan permintaan Pemohon untuk diberikan izin berpoligami itu benar adanya. Untuk itu, hakim memerlukan alat bukti.

Alat bukti, yang digunakan di dalam penyelesaian perkara izin poligami ini adalah alat bukti surat dan saksi. Surat yang dijadikan alat bukti jumlahnya beragam sedangkan saksi yang dihadirkan sejumlah dua orang. Dengan dua alat bukti tersebut, syarat-syarat yang diperlukan bagi Pemohon supaya permohonan izin poligaminya dapat diproses dan diperiksa lebih lanjut sudah terpenuhi. 
Kedua, tahap mengkualifikasi. Pada tahap ini, hakim menggali sebanyak-banyaknya keterangan secara lisan atau tertulis, baik dari Pemohon, Termohon, atau para saksi yang dihadirkan. Tujuannya, adalah menentukan peristiwa konkret yang dialami Pemohon itu adalah peristiwa hukum sehingga dasar permohonannya dapat diterima. Selain itu, di tahap ini pula hakim mencoba mencari dasar hukum yang menurutnya sesuai. Dengan kata lain, upaya recbtvinding hakim Pengadilan Agama Jombang dimulai pada tahap kedua ini.

Tahap yang terakhir adalah tahap mengkonstituir. Artinya, hakim sampai pada upaya final untuk menjatuhkan putusan atau penetapan. Dalam penelitian ini, produk yang dihasilkan adalah "Putusan". Hakim Pengadilan Agama Jombang pada akhirnya memberikan izin kepada Pemohon untuk berpoligami. Meskipun, ia berpaling dari bunyi-bunyi pasal yang ada di dalam Kompilasi Hukum Islam maupun Undang-undang Nomor 1 Tahun 1974 tentang Perkawinan.

2. Penemuan Hukum

Sebelumnya dijelaskan bahwa terdapat dua teori besar dalam penemuan hukum yang tersebar di banyak referensi hukum. Teori pertama adalah teori interpretasi hukum dan yang kedua adalah teori konstruksi hukum. Achmad Rifa'i menambahkan satu model baru, yakni hermeneutika hukum meskipun dalam praktiknya masih jarang digunakan oleh hakim. Perbedaan yang paling mendasar: jika metode interpretasi dan konstruksi lebih banyak menekankan aspek legalitas, maka metode hermeneutika tidak hanya melihat sisi teks/ legalitasnya saja, tetapi juga termasuk aspek penerapan/konteksnya.

Menurut peneliti, semua jenis metode penemuan hukum digunakan hakim Pengadilan Jombang dalam menyelesaikan perkara izin poligami ini adalah metode interpretasi dan hermeneutika hukum. Ia tidak menggunakan sama sekali konstruksi hukum. Dengan kata lain, hakim Pengadilan Agama Jombang menggunakan metode yang jarang diaplikasikan oleh hakim-hakim di lingkungan peradilan lainnya.

Bukti bahwa metode interpretasi hukum digunakan adalah di saat hakim menimbang perkara, ia menjadikan Pasal 4 Ayat (2) 
UU Perkawinan yang secara detail mengatur tentang syarat alternatif diperbolehkannya poligami sebagai acuan berpikirnya. Syarat alternatif yang dimaksud adalah:

1) Istri tidak dapat menjalankan kewajibannya sebagai istri;

2) Istri mendapat cacat badan atau penyakit yang tidak dapat disembuhkan;

3) Istri tidak dapat melahirkan keturunan.

Kemudian hakim PA Jombang berlanjut ke Pasal 5 Ayat (1) UU Perkawinan yang mengatur tentang syarat kumulatif dikabulkannya poligami yang terdiri dari:

1) Adanya persetujuan dari istri/istri-istri;

2) Adanya kepastian bahwa suami mampu menjamin keperluan hidup istri-istri dan anak-anaknya;

3) Adanya jaminan bahwa suami akan berlaku adil terhadap istri-istri dan anak-anaknya.

Hakim di PA Jombang memaknai pasal tersebut secara letterlijk (interpretasi gramatikal). Tidak ada kata-kata yang ditafsirkan lebih dari itu. Bahwa Pemohon harus memenuhi satu di antara syarat alternatif yang tersebut di dalam Pasal 4 Ayat (2) UU Perkawinan dan keseluruhan dari syarat kumulatif yang tersebut di Pasal 5 Ayat (1)-nya.

Menurut interpretasi gramatikal, Pemohon sepenuhnya tidak memiliki hak untuk melakukan poligami. Tetapi, Pemohon memberikan dalih lain bahwa istrinya tidak bersedia untuk diajak tinggal di Kabupaten Malang dan memilih menetap di Kabupaten Jombang karena harus merawat ibunya. Atas dasar itu, Pemohon menyebut istrinya tidak mampu memenuhi kewajibannya sebagai istri. Dengan kata lain, ia memenuhi syarat alternatif yang tersebut pada Pasal 4 Ayat (2) Huruf (a).

Oleh karena Pemohon menyebut demikian, maka hakim tidak berhenti dengan hanya mengandalkan interpretasi gramatikal terhadap kalimat "Istri tidak dapat menjalankan kewajibannya sebagai istri”. Untuk itu, hakim kemudian menggunakan metode konstruksi hukum. Tujuannya adalah menilai argumentasi Pemohon yang menilai Termohon tidak mampu memenuhi kewajibannya.

Metode konstruksi yang digunakan hakim PA Jombang adalah metode penyempitan hukum (rechtsvervinjings). Tujuannya adalah 
menilai bunyi pasal atau hukum yang terlalu abstrak untuk dapat diimplementasikan secara praktis. Pemohon berpandangan bahwa bentuk konkret dari Pasal 4 Ayat (2) Huruf (a) yang tertulis "istri yang tidak mampu menjalankan kewajiban" salah satunya adalah tidak bersedia patuh terhadap suami untuk diajak tinggal bersama. Oleh sebab itu, hakim perlu menilai kebenaran dalih pemohon.

Pasal 4 Ayat (2) Huruf (a) memang mengandung pengertian yang umum. Sebagaimana bunyi pasal $1365 \mathrm{KUH}$ Perdata yang di berbagai referensi hukum dijadikan contoh dari penerapan metode penyempitan hukum. Pasal tersebut mengatur bahwa, "Tiap perbuatan melawan hukum yang membawa kerugian besar kepada orang lain, mewajibkan orang yang karena salahnya menertibkan kerugian itu, mengganti kerugian tersebut." Frasa "Perbuatan melawan hukum" lingkupnya terlalu umum dan abstrak sehingga sulit untuk diterapkan. Untuk itu, Hoge Raad memberikan batasanbatasan terhadap perbuatan tertentu saja yang dapat dikategorikan perbuatan melawan hukum.

Upaya tersebut juga dilakukan oleh hakim PA Jombang. Namun, hakim berpandangan bahwa keadaan Termohon bukanlah wujud kelalaian atau ketidakmampuan seorang istri untuk memenuhi kewajibannya. Menurut penilaian hakim, Termohon memiliki alasan logis yang dapat diterima. Penolakannya terhadap ajakan Pemohon atas dasar bakti untuk merawat orang tuanya tidak dikategorikan sebagai bentuk konkret dari Pasal 4 Ayat (2) Huruf (a). Oleh karenanya, Pemohon dianggap tetap tidak memenuhi satu pun syarat alternatif.

Tidak berhenti di sana, Pemohon memberikan argumentasi lain bahwa dirinya berada di dalam situasi yang tidak afirmatif untuk mempertahankan pernikahan monogami. Maksudnya, Pemohon mengaku sering menetap di Kabupaten Malang untuk keperluan pekerjaan dan hanya pulang ke Kabupaten Jombang saat libur akhir pekan. Dengan kata lain, hari-hari Pemohon banyak dihabiskan untuk kepentingan pekerjaan dan sedikit meluangkan waktu untuk berkumpul dengan keluarga. Kemudian, Pemohon juga menuturkan bahwa dirinya sudah berkenalan lama dengan seorang janda di Kabupaten Malang sehingga dikhawatirkan akan terjadi perbuatan 
yang dilarang norma agama jika permohonannya untuk berpoligami tidak dikabulkan.

Atas fenomena tersebut, hakim PA Jombang menggunakan interpretasi hermeneutika. Fakta yang dituturkan pemohon sudah tidak lagi tercakup di dalam hukum positif yang ada baik di UU Perkawinan maupun KHI. Pada titik ini, naluri hakim menilai bahwa sudah saatnya keluar dari jaring-jaring legalitas hukum. Tidak cukup kalau hanya mengandalkan interpretasi dan konstruksi hukum. Ia perlu membentangkan horizon pemikirannya ke arah kontekstualisasi hukum.

Dilema antara positivisme dan realisme hukum pun dimulai. Di satu sisi, jika hakim menuruti bunyi undang-undang maka tertutup jalan bagi Pemohon untuk mendapatkan izin berpoligami. Namun, jika hakim lebih "memihak" kepada Pemohon maka seakan-akan menerobos ketentuan undang-undang. Dari dua pertimbangan dilematis tersebut, hakim lebih memilih aspek praktis dari poligami itu sendiri. Hakim tidak meyakini bahwa hukum yang sebenarnya adalah hukum yang apa adanya diatur di dalam undang-undang (law is as it is), tetapi hukum yang sebenarnya adalah hukum yang seharusnya ada dalam situasi tertentu (law is as it should be). Pada akhirnya, syarat alternatif poligami yang tersebut di dalam Pasal 4 Ayat (2) Huruf (a) dikesampingkan oleh hakim PA Jombang. Pemberian izin bagi Pemohon dinilai lebih urgen.

Berdasarkan berbagai data yang diperoleh selama penelitian di lapangan, bahwa temuan penelitian dapat dirumuskan sebagai berikut :

1. Keadilan gender tercermin di dalam proses beracara yang ada di Pengadilan Agama. bahwa hakim di Pengadilan agama dalam mempertimbangkan pemberian izin poligami masih memerlukan persetujuan dari istri lama baik secara tertulis maupun secara lisan. Di samping itu, hakim juga perlu memeriksa dalil-dalil penolakan seorang istri untuk dimadu. Apabila masuk akal, maka akan diterima. Terbukti, di PA Jombang hakim menerima alasan Termohon (istri) atas keberatannya mengikuti Pemohon (suami) tinggal di Malang.begitu juga pengakuan adanya harta bersama antara suami dengan isteri terlama. 
2. Nalar rechtvinding hakim PA Jombang adalah percampuran dari Metode, yaitu metode interpretasi dan metode konstruksi yang kedua masih bersinggungan dengan sisi legalitas suatu hukum.

Keabsahan poligami di Indonesia adalah manifestasi dari praktik yang diterima secara dilematis. Di satu sisi, masyarakat Indonesia mayoritas beragama Islam dan di dalam ajaran ini, poligami bukanlah sesuatu yang menyalahi syariat. Sebab, mayoritas ulama mengijtihadi kebolehannya atas dasar kalam Tuhan dan sunah Nabi Muhammad Saw. Namun, di sisi lain diskursus ilmiah hari ini mempersoalkan praktik poligami yang dilegalkan. Alasannya satu: kesetaraan perempuan. Poligami melukai hak-hak kemanusiaan. Tidak selayaknya perempuan menerima peran hidup sebagai orang kedua yang bisanya tunduk dalam kekuasaan laki-laki. Kendati demikian, setidaknya masyarakat tetap menerima keputusan setiap individu untuk memilih antara ber-monogami atau ber-poligami. Tetapi stigma negatif sepertinya akan sulit dihilangkan terhadap institusi poligami.

Terlepas dari silang sengkarut tersebut, argumentasi peneliti berada pada posisi menguatkan atau membenarkan praktik poligami yang dilegalkan. Tuduhan terkait pencederaan hak-hak perempuan sebenarnya tidak tampak sekali jika kita memandang proses atau kronologi yang harus dilalui seseorang jika ingin melangsungkan perkawinan poligami. Artinya, proses persidangan di Pengadilan Agama adalah wahana kontestasi yang sebenarnya menunjukkan kepedulian negara untuk melindungi hak-hak warga negaranya.

\section{Penutup}

Dari pemaparan penelitian ini dapat ditarik benang merah sebagai berikut:

1. Keadilan gender tercermin di dalam proses beracara yang ada di Pengadilan Agama. Tuduhan bahwa poligami adalah bentuk perilaku bias gender yang merugikan perempuan tidaklah selalu benar. Pada dasarnya, hakim di Pengadilan agama mana pun tidak akan pernah melalaikan istri terlama ketika sang suami akan berpoligami. Terbukti, di PA Jombang hakim menerima alasan Termohon (istri) atas keberatannya mengikuti Pemohon (suami) tinggal di Malang. 
2. Nalar rechtvinding yang hakim PA Jombang gunakan adalah percampuran dari berbagai metode. Metode tersebut meliputi metode interpretasi dan metode konstruksi yang kedua masih bersinggungan dengan sisi legalitas suatu hukum. Kemudian, hakim juga menggunakan metode hermeneutika untuk menggali kebenaran secara kontekstual. Hukum baginya perlu menyesuaikan diri dengan masyarakat apabila dipandang tidak relevan lagi. Hakim mempertimbangkan penerapan hukumnya dibandingkan dengan aspek legalitasnya.

Penelitian ini masih jauh dari kriteria sempurna. Tetapi, peneliti akan memberikan keluasan ruang dan waktu bagi para pembaca dari kalangan mana pun untuk menganalisis dan menyajikan pemikiranpemikiran baru. Tujuannya demi menambah validitas penelitian. Peneliti juga mempersilakan semua orang apabila melakukan penelitian bandingan. Artinya, fokus dan objeknya memiliki kesamaan dengan peneliti namun analisisnya berlainan.

\section{Daftar Pustaka}

Ahmad Ali. Menguak Tabir Hukum: Suatu Kajian Filosofis dan Sosiologis. Jakarta: Gunung Agung, 2002.

Ahmad Kamil. Filsafat Kebebasan Hakim. Jakarta: Kencana, 2014.

Aḥmad Riḍā. Mưjam Matn al-Lughah. Juz 4. Beirut: Dār Maktabah al-Hayāh, 1958.

Ahmad Rifai. Penemuan Hukum oleh Hakim dalam Perspektif Hukum Progresif. Jakarta: Sinar Grafika, 2010.

Ahmad Syukron. "Islam dan Feminisme: Perspektif Rekonstruksi Hukum Islam", dalam Muwāąh. Vol.1, No. 2, 2009.

Ahmad Warson. Kamus Bahasa Arab-Indonesia. Yogyakarta: Pustidaka Progresif, 1990.

Alex Sobur. Analisis Teks Media: Suatu Pengantar untuk Analisis Wacana, Analisis Semiotika, dan Analisis Framing. Yogyakarta: PT. Tiara Wacana Yogya, 2000.

Amina Wadud. Inside the Gender Jihad: Women's Reform in Islam. London: Oneworld, 2006.

Qur'an and Woman: Rereading the Text from Woman's Perspective. Oxford: Oxford University Press, 1999. 
Anselm Strauss \& Juliet Corbin. Dasar-Dasar Penelitian Kualitatif. Surabaya: PT. Bina Ilmu Ofset, 1997.

Asep Syarifudin Hidayat. "Pengaruh Wacana Gender dalam Pembangunan Hukum Keluarga di Indonesia". Jurnal Cita Hukum, Vol. 1, No. 1, 2013.

Asghar Ali Engineer, The Qur'an Women and Modern Society: Second Edition. New Delhi: New Dawn Press, 2005.

Azni. "Izin Poligami di Pengadilan Agama: Suatu Tinjauan Filosofis". Jurnal Risalah, Vol. 26, No. 2, 2015.

Bambang Sutiyoso. Metode Penemuan Hukum. Yogyakarta: UII Press, 2006.

Dadang Kahmad. Metode Penelitian Agama, Perspektif Ilmu Perbandingan Agama. Bandung: Pustaka Setia, 2000.

Departemen Agama RI. al-Jumānatul 'Ālì: al-Qur'an dan Terjemahannya. Bandung: J-Art, 2004.

Gavin W. Jones. Marriage and Divorce in Islamic South East Asia. Oxford: Oxford University Press, 1994.

Ibn al-Manzūūr. Lisān al-'Arab. Juz 2. Beirut: Dār al-Șādir, tt.

Ibnu Musthafa. Wanita Islam Menjelang Tabun 2000. Bandung: alBayan, 2000.

J. R. Raco. Metode Penelitian Kualitatif: Jenis, Karakteristik, dan Keunggulannya. Jakarta: Grasindo, 2010.

Jazim Hamidi. Hermeneutika Hukum, Sejarah, Filasafat dan Metode Tafsir. Malang: UB Press, 2011.

Johny Ibrahim. Teori dan Metodologi Penelitian Hukum Normatif. Malang: Bayumedia, 2011.

Kaelan. Metode Penelitian Agama Kualitatif Interdsipliner. Yogyakarta: Paradigma, 2010.

Lexy J. Moloeng. Metodologi Penelitian Kualitatif. Bandung: PT Remaja Rosdakarya, 2000.

M. Syamsudin. Konstruksi Baru Budaya Hukum Hakim Berbasis Hukum Progresif. Jakarta: Kencana, 2012.

Mansour Fakih. Analisis Gender dan Transformasi Sosial. Yogyakarta: Pustaka Pelajar, 1997.

Moh Fakhry. "Hukum Perkawinan di Indonesia: Kajian Hukum Berkeadilan Gender dalam Kerangka Feminist Legal Theory". Muwāāăh, Vol. 7, No. 2, Desember, 2017. 
Nasaruddin Umar. Argumentasi Kesetaraan Gender Perspektif al-Qur'an. Paramadina: Jakarta, 1999.

Nur Kholis dkk. "Poligami dan Ketidakadilan Gender dalam Undang-undang Perkawinan di Indonesia". al-Abkam, Vol. 27, No. 2, 2017.

Petrus C.K.L. Bello. Hukum dan Moralitas: Tinjanan Filsafat Hukum. Jakarta: Erlangga, 2012.

Qurratul Ainiyah. Keadilan Gender dalam Islam: Konvensi PBB dalam Perspektif Mazhab Shafi'i. Malang: Intans Publishing, 2015.

Robert Bogdan \& Steven J. Taylor. Pengantar Metode Penelitian Kualitatif. Surabaya: Usaha Nasional, 1992.

Shinta Dewi Rismawati. "Konstruksi Hukum Perkawinan di Indonesia: Perspektif Kaum Feminis". Munāąăh, Vol. 9, No. 2, 2017.

Siti Musdah Mulia. Islam Menggugat Poligami. Jakarta: PT Gramedia Pustaka Utama, 2007.

Sudikno Mertokusumo. Penemuan Hukum: Sebuah Pengantar. Yogyakarta: Liberty, 2009.

. Bab-bab tentang Penemuan Hukum. Bandung: PT. Citra Aditya Bakti, 1993.

Tatang M. Amin. Menyusun Rencana Penelitian. Jakarta: Rajawali Press, 1990.

William Morris. The Heritage Illustrated Dictionary of English Language.

Vol. 2. Boston: Hought Mifflin Company, 1979.

Zamroni. Pengantar Pengembangan Teori Sosial. Yogyakarta: PT. Tiara Wacana, 1992.

"Detail Kabupaten Jombang" dalam depdagri.co.id, diakses tanggal 2 Juni 2019.

"Sejarah Pengadilan Agama Jombang" dalam http://www.pajombang.go.id/sejarah-pa, diakses pada 1 Januari 2019.

Husni Tamrin, Hakim PA Kab Kediri, Wawancara, Rabu, 21 Agustus 2019.

Siti Munadhirah, Hakim PA Kab Lamongan, Wawancara, Jum`at, 30 Agustus 2019. 